\title{
The Challenges of Developing Tourism Events in Bromo Tengger Semeru National Park
}

\author{
Muhammad lqbal Rosyidi* \\ Deputy Assistant of Industry and Tourism Regulations, Ministry of Tourism Republic of Indonesia, Jakarta, Indonesia
}

\section{Abstract}

Tourism in Bromo Tengger Semeru National Park has been considered important for national earning and local community development. As a conservation area, the development of tourism in Bromo Tengger Semeru should consider conservation principles. The purpose of this research is to identify the challenges of developing tourism events in TNBTS especially dealing with sustainable development. The research method used is qualitative method with descriptive analysis technique. In-depth interviews were conducted to explore the perceptions of the government, organizer, and community regarding the conduct of tourism event in TNBTS. The literature study was conducted to provide more complete data and information. Furthermore, researcher conduct field observations twice, the first observation was during the Yadnya Kasada event and the second one was on normal days. This research has successfully identified three challenges of tourism event development in TNBTS namely the institutional, event sustainability, and rivalry with competitors.

Keywords: event tourism, national park, sustainable development.

\section{INTRODUCTION}

The event is essentially an activity and a planned public or social occasion. It is simply defined as something that happens temporarily in order to collect a number of people [1]. It usually shows a ritual or ceremony and sometimes, it is a unique activity. Meanwhile, Bowdin et al states that an event is central to the culture of humankind [2]. However, the event is categorized into a private and public event. A public event is the right category to represent the event tourism in this discussion.

The term tourism event is often related to and replaced with the terms festival and carnival. However, some authors prefer to use event tourism [3,4,5]. Donald Getz used the term tourism event in 1998 to describe the unique activity held by certain attractive people. He adds that tourism event is the whole of planning, developing, and marketing strategy of tourist attractions to maximize the tourist participation either as a main or an alternative attraction [6]. Nevertheless, other author used various terms such as special event, festival tourism, and cultural event, which has a similar definition and the same intent.

Besides having uniqueness, there are some characteristics of the tourism events; Shone and

\footnotetext{
${ }^{*}$ Correspondence address: Muhammad Iqbal Rosyidi Email: iqbalrosyidi@gmail.com Address: Film Building, Ministry of Tourism Indonesia Letjen MT Haryono Street, Kav. 47, Pancoran, South Jakarta, Jakarta Special Capital Region, 12770.
}

Parry argue that a tourism event has characteristics such as uniqueness, perishability, ambiance and service, labor-intensive, fixed timescale, intangibility, ritual or ceremony, and personal interaction [7]. Uniqueness is the main key of a tourism event and comes from the surrounding environment, the visitors, and the performed attractions. The tourism event cannot be replicated elsewhere at the same time. Tourism events also tend to be intangible because visitors do not get a certain object but they feel the experience in the form of activity. Rituals and ceremonies also make tourism event special. Furthermore, the success of a tourism event cannot be achieved without the service of the event organizer and the atmosphere of the event.

Nowadays, some developed countries have set tourism event out as a tourism movement, for example, Singapore, the so-called event capital in Asia. Singapore has a variety of events, both modern and traditional, both international and local level. For instance, every year Singapore gets an opportunity to hold GrandPrix Formula 1 that attracts the attention and visits of foreign tourist from the adjacent country.

Singapore successfully organized various kinds of tourism events. It is because besides having limited natural resources as a natural tourist attraction, also due to the professional human resources in organizing a tourism event. Singapore effectively utilized the events to draw foreign tourist visits. 
As well as Singapore, Indonesia also has various tourism events; even more superior in respect of quantity. Through the cultural diversity, Indonesia has an enormous potential to hold a hundred events each year. Currently, those events are held in many places, including sea, land, and air. They are even organized in a number of national parks, including Bromo Tengger Semeru National Park (TNBTS).

In early 2017, the Government of Indonesia determined TNBTS as one of the priority tourist destinations. One of the purposes of this determination is to equalize tourism potential and to develop alternative tourist destinations besides Bali. The program is often known as The 10 New Bali. TNBTS is the National Park situated in Malang Regency, Pasuruan Regency, Probolinggo Regency, and Lumajang Regency. Although it's located administratively in East Java, based on the Regulation of the Minister of Forestry Number P19/Menhut/2004, Bromo Tengger Semeru National Park Central Office, under the Ministry of Environment and Forestry has authorization to organized TNBTS $[8,9]$.

Among the priority tourist destinations, TNBTS is the only destination which has naturebased tourist destination in the form of mountains/volcanoes. Since 1920, TNBTS, especially Mount Bromo, was well-known among the Dutch elite who were ruling over Indonesia. There are two mountains which become the attraction as well as the icon of the area, Mount Bromo and Semeru. However, Mount Bromo is more attractive, and maybe more well-known, than Semeru for the tourists. This different recognition is due to the uniqueness of the shape of the mountain and there is the crater that is still actively producing sulfur fumes. This mountain also has the sea of vast sand of 5.250 ha located at an altitude of $\pm 2.100 \mathrm{~m}$ above sea level. This combination becomes a landscape that cannot be found in any tourist destinations in Indonesia.

The prominent tourist attractions offered in this area are the experience of catching the sunrise in Penanjakan, horse riding in the sea of sand, and climbing up the peak to see the crater $[10,11]$. Foreign tourists also able to enjoy other activities such as hiking, beholding the landscape, seeing the crater, horse riding, photography, camping, visiting Pura, and jeep riding [12]. Those things show that TNBTS offers various experiences and the image of TNBTS is currently more influenced by the landscapes.
As we know, a good destination image is a manifestation of the success of a tourism development and marketing [13]. In fact, a tourism event can be one of the supporting factors as the image of a tourist destination [14]. The events, especially hallmark events, play an important role in attracting tourists to a destination and directly build the tourist destination image. The hallmark events act as a catalyst for the tourist destination development that serves images or symbols. Hallmark event also becomes a solution to the problem product differentiation of a tourist destination [15].

So far, various forms of tourism events have been organized in the area and around TNBTS. Those events are arts and cultural, sports events, and adventure events. From all events, Yadnya Kasada is the most popular and interesting event for tourist, especially for international visitors. Yadnya Kasada or Kasodoan is an offering ceremony performed by the Tenggerese to Hyang Widi Wasa (The God) and held once a year in Kasada month [16,17]. However, there are other routine events, for example, BTS UItra and Jazz Gunung. BTS Ultra is a sport event within TNBTS while Jazz Gunung is a jazz music festival held around TNBTS area.

Some previous studies have tried to analyze tourism events in Indonesia, such as Mahadewi [5]. She examined the practice of the implementation of attractions, tourism products, and tourism events that are related to the theory by taking the case in Bali [5]. The research aims to find out the impacts of tourism events. On the other hand, Susanti has attempted to describe Event Tour de Singkarak and linked it to sustainable tourism marketing [18]. The positive relation between tourism events with the number and the motivation of tourist makes the event tourism research interesting to be studied further.

In this study, the events, that have a positive influence in improving the number of tourists, are held in the area with limited utilization. As it is known, TNBTS is a protected area at Category II by the World Conservation Union. As well as other human activities, tourism events also utilize, exploit, and influence the natural resources in the host areas. The development of events that refer to the principle of sustainability becomes crucial, especially the impacts and the benefits for the triple bottom line, i.e. Social, Environment, and Economy $[9,19]$.

The sustainability of the tourism event does not only refer to the triple bottom line but it also 
concerns the sustainability of event performance [20]. Sometimes the organizer decided to stop the performance of events because it becomes unattractive and quiet enthusiasts in the previous performance. As an example is Jatinegara Tourism Festival in East Jakarta. This festival is a cultural festival that performs certain Betawi cultures and other cultures outside Betawi, such as Orkes Keroncong and Reog Ponorogo. It began in 2011 with the different packaging and theme every year. However, in 2016, that festival is no longer held because of quiet enthusiasts. This untenable event shows that this event has an unsustainable implementation.

Nevertheless, referring to Getz's opinion in various studies on tourism events, the social aspect and especially environmental aspect receives less attention from many authors [4]. Thus, this research focuses on and tries to provide perspective and discussion, not only the economic aspect, but also social and environmental aspects of the challenges of developing tourism event in TNBTS. Through this research, the stakeholders are to be able to anticipate the challenges in organizing the tourism event in TNBTS.

\section{RESEARCH METHOD}

The type of this research is qualitative research focusing on describing and explaining the existing phenomena in the field. The researcher decides to use descriptive qualitative as the analyzing method. By using descriptive qualitative, the researcher intended to show and explain accurate descriptions and illustrations of tourism events occurring in TNBTS.

However, this research also has limitations. First, it is about geographical aspect. Because of the vastness of TNBTS area, the scope of the data collection is only limited to the TNBTS area which located in Probolinggo Regency. Second, it comes from the substantial aspect. The triple bottom line, which considered important to be studied, are confronted with limited costs and time. Consequently, the discussion about those three aspects is not in depth elaborated and quantified. Those three aspects are analyzed using qualitative analysis technique based on the data collected in the field.

\section{Data Collection Method}

The researcher obtained the data through observation, interview, and literature study. The observation was made twice, i.e., at Yadnya Kasada event and on a normal day. We conduct the interview with TNBTS Central Office (as the management of TNBTS), the Department of Culture and Tourism of East Java, and the residents of Ngadisari Village and Cemoro Lawang Village in Probolinggo Regency.

The interview with TNBTS Central Office and the Department of Culture and Tourism of East Java is carried out to gain information on how the events are held in TNBTS and their perceptions of those events. Furthermore, the interviews with the community representatives were done to get public perceptions of the events conducted in TNBTS. Meanwhile, the literature study was conducted to collect the secondary data and information, such as the regulations.

\section{RESULT AND DISCUSSION}

The people of Tengger in TNBTS has held a ritual ceremony in Mount Bromo and surrounding areas since a long time ago. At that time, Yadnya Kasada and Karo were the most sacred ceremony. Those traditional ceremonies are the offering ceremonies to God held by Tengger people in the sea of sand and the crater of Mount Bromo.

The Tenggerese held Yadnya Kasada on the $14^{\text {th }}, 15^{\text {th }}$, or $16^{\text {th }}$ of the Kasada Month while Karo Ceremony is held in Karo Month (the second month of Tengger Society calendar system). At the first time, Yadnya Kasada and Karo were merely considered as traditional ceremonies. However, since 2000s, those ceremonies, especially Yadnya Kasada, started to attract tourists' attention as a unique and interesting spectacle. This shift happened because of the uniqueness of the ceremony which cannot be found in any places other than Mount Bromo. Until now, Yadnya Kasada becomes one of the events widely known by people and become the icon of TNBTS. Moreover, Kasodo is important for Tenggerese to express their gratitude to God and to be preserved as a sustainable Tengger culture as well $[9,21]$.

\section{The Scale and the Forms of Tourism Events}

Over the last decade, various tourism events have been successfully arranged in TNBTS area (Table 1). Most events are annual agenda. For example Jazz Gunung that has been existed since 2009. Another example is a sports event namely BTS Ultra which has been annually held since 2013 and attracted domestic and foreign runners to participate in that competition. However, in terms of organizing, the events in TNBTS are 
predominantly arranged by and from local communities and the event organizers.

Related to the event management, based on the interview, the Department of Culture and Tourism of East Java states:

"Province (the Department of Culture and Tourism) only supports them through electronic and print media and also exhibitions."

It shows that the Department is merely concerned about the promotion and the marketing of events. Furthermore, according the information from the Central Office of TNBTS, the private sector have enormous initiatives to hold events in TNBTS. In this case, the Central Office of TNBTS tends to be more concerned with the conservation in TNBTS. Nevertheless, all events held in TNBTS have to get a recommendation letter from TNBTS management. The recommendation letter is the approval statement from the Central Office to the event organizer after getting some consideration.

\section{The Impacts of Tourism Events in TNBTS}

Before discussing the challenges, it is necessary to identify the impacts of a tourism event. There are, at least, four dimensions of the impact/benefit of cultural festivals [22]. The impact is classified into two types, which are obtained by the public and the individual as well as from the intrinsic and extrinsic dimensions. Intrinsic dimensions can be stated to be essential and tend to be intangible. Meanwhile, the extrinsic dimension is the impact/benefit that can be captured by the eye and tend to be and comes from outside. Extrinsically, the impacts of tourist events for individuals include health, regular behavior, and expenditure. As for the community, tourism events have an impact on economic, social, environmental, and community educational and public welfare value (Figure 1).

Table 1. The Events held in TNBTS

\begin{tabular}{|c|c|c|c|c|c|}
\hline $\begin{array}{l}\text { Event } \\
\text { Scale }\end{array}$ & Tourism Events & $\begin{array}{l}\text { Typology of } \\
\text { the Events }\end{array}$ & Information & Initiatives & Model \\
\hline $\begin{array}{l}\text { Hallmark } \\
\text { Event }\end{array}$ & Yadnya Kasada & Cultural Event & $\begin{array}{l}\text { The offering ceremony of crops or } \\
\text { livestock (Ongkak) that have been } \\
\text { harvested as a gratitude to nature. }\end{array}$ & Tengger People & $\begin{array}{l}\text { Nature as the } \\
\text { background }\end{array}$ \\
\hline \multirow[t]{3}{*}{$\begin{array}{l}\text { Regional } \\
\text { Event }\end{array}$} & a. Karo & Cultural Event & $\begin{array}{l}\text { The offering ceremony for ancestral } \\
\text { spirits to avoid catastrophe and to } \\
\text { commemorate the origin }\end{array}$ & Tengger People & $\begin{array}{l}\text { Nature as the } \\
\text { background }\end{array}$ \\
\hline & $\begin{array}{l}\text { b. Bromo } \\
\text { Marathon }\end{array}$ & Sport event & $\begin{array}{l}\text { Run Competition in Bromo Tengger } \\
\text { Semeru area }\end{array}$ & Event Organizer & $\begin{array}{l}\text { Nature as the } \\
\text { background }\end{array}$ \\
\hline & c. Jazz Gunung & $\begin{array}{l}\text { Arts and } \\
\text { Entertainment }\end{array}$ & $\begin{array}{l}\text { International jazz concert event, having } \\
\text { ethnic nuance held annually in } \\
\text { Amphitheater Jiwa Jawa Resort Bromo }\end{array}$ & Event Organizer & $\begin{array}{l}\text { Nature as the } \\
\text { background }\end{array}$ \\
\hline \multirow[t]{2}{*}{$\begin{array}{l}\text { Local } \\
\text { Event }\end{array}$} & a. Unan-Unan & Cultural Event & $\begin{array}{l}\text { The ceremony to honor the ancestral } \\
\text { spirits, expel the evil spirits from the } \\
\text { village by giving offerings to redi-redi } \\
\text { (volcanos) by slaughtering cattle, i.g. a } \\
\text { buffalo }\end{array}$ & Tengger People & $\begin{array}{l}\text { Nature as the } \\
\text { background }\end{array}$ \\
\hline & $\begin{array}{l}\text { b. Eksotika } \\
\text { Bromo }\end{array}$ & $\begin{array}{l}\text { Arts and } \\
\text { Entertainment }\end{array}$ & $\begin{array}{l}\text { A dance-drama/ballet performance from } \\
\text { various arts in East Java }\end{array}$ & Event Organizer & $\begin{array}{l}\text { Nature as the } \\
\text { background }\end{array}$ \\
\hline
\end{tabular}




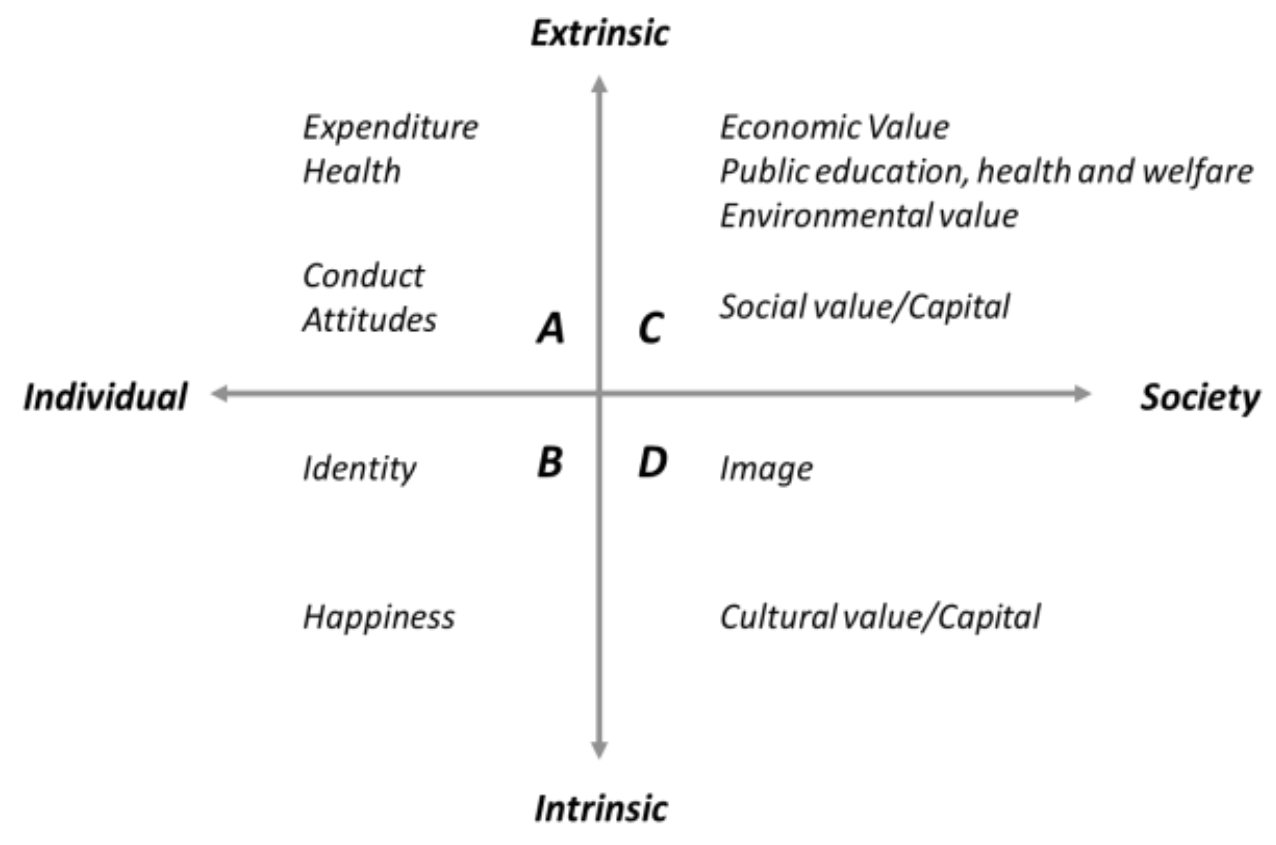

Figure 1. Benefit Dimention of the Tourism Events according to Mc Carthy et al. (2004). Source: Lundberg et al. [22]

Besides carrying the impacts on the individual (personal impacts), and on public (external impacts), tourism events have the impacts on an institution (organizational impacts) [1]. Those organizational impacts can be finance, human resources, institutional capacity, and marketing. However, the focus of this research is the impact on society in general which can be observed (extrinsic impacts).

Tourism events in TNBTS also have an impact on economic, social or environmental aspects; both micro and macro. The impact of every tourism event is various. For example, BTS Ultra and Bromo Marathon that involve many international runners. According to one of the residents in Ngadisari Village, when the event is held, local people who work as farmers change their jobs for a while to be volunteers and rent out the lodging, horses, and jeeps.

Meanwhile, in other events, such as Yadnya Kasadnya and Karo, which the community become the main actors, they leave their daily work to get more focused on the event. Although there is information on the increased opportunity to have higher income at the time of the event is held, this research has not measured quantity percentage of the community income rise when the event occurs.

In the economic aspect, the most visible impact of the tourism event is the increased revenue from the increasing entrance ticket sales for TNBTS. The event goers who want to participate or just want to watch the event are required to pay the entrance fee into TNBTS area. In addition, the growing of event goers increased the sales of consumer goods such as snacks sold by the Tengger community within TNBTS and the surrounding areas. Unfortunately, the amounts of community and management's incomes and the tourism multiplier effect have not been the focus of this research.

In social aspect, the various tourism events held in TNBTS make the interviewed people in Cemoro Lawang Village proud, especially of Yadnya Kasada, which is a tradition of Tenggerese. Yadnya Kasada can also enhance the brotherhood among them.

Another impact is social cohesion [23]. Tourism events, especially indigenous cultural festivals can enhance the sense of kinship among the event committee. At Yadnya Kasada and Karo, social cohesion occurs among local Tengger. Meanwhile, at BTS Ultra, Jazz Gunung, and Bromo Marathon, social cohesion could occur among the communities living around TNBTS, the event organizers, and the event goers.

A tourism event can directly increase the number of visitors in TNBTS. For example, sports events like Bromo Marathon and BTS Ultra. Both events involve a thousand participants. The presence of such participants means also increased demand for accommodation, such as lodging and jeeps. But, the growing number of 
tourists also raises the amount of consumption that affects the increasing amount of garbage in TNBTS area. A villager from Ngadisari said,

"Every time an event is held, we have a serious garbage problem. The more visitors come, the more garbage they will leave."

This phenomenon shows that there is a social cost, which is a lot of garbage because of a tourism event. The evidence showed at Yadnya Kasada, where people 'throw' their offerings to the crater of Mount Bromo. The offerings are in the forms of livestock and comestibles. Although some of the offerings are collected again by the local people, common people consider the left offerings as garbage.

\section{The Challenges in Tourism Events Development}

A challenge can be defined as something that tests the ability of a person and organization, and it deserves to be overcome by their resources. In general, there are five challenges of tourism event development. First, it is a paradigm shift from supply-side to demand side. An event organizer needs to change the event paradigm and orientation that has been used previously. One thing that needs to be improved is how a tourism event can meet the visitors' expectations by considering the current capacity. Second is a policy change, from top-down policy to be more bottom-up. This indicates that in holding a tourism event, an event organizer needs to explore people's aspirations.

The third is managing the event portfolio rather than just focusing on the specific tourism event. The organizer needs to weigh in managing various tourism events as a portfolio, so it can be promoted to tourists. The portfolio shows the organizer's professionalism in managing various events. The fourth challenge is creating and promoting an event and the last one is ensuring that development of a tourism event based on the principles and the models of sustainable development.

The development of tourism events in TNBTS is not without challenges. The first observed challenge is the institutional problem. Based on the observations and interviews with the community representatives of Ngadisari and Cemoro Lawang villages, there is a disharmony between programs and policies between the Central Office of TNBTS and the Local Government in developing tourism in TNBTS. It affects the development of tourism events in TNBTS area. As a result, the development of tourism events comes more from the community (private sector). The local government does not consider tourism events as a strategic way to regional tourism development. Communities around TNBTS also have not been trained to conduct a tourism event professionally. Therefore the commitment and mutual trust among the stakeholders becomes the key to a successful tourism development at the local level [3].

The second challenge is related to the sustainability of tourism events. Until now, there is no data and information stating that the tourism event held in TNBTS failed. Precisely, some tourism events that exist, such as BTS Ultra 100, Bromo Marathon, Jazz Mountain, and Yadnya Kasada gain great attention from the event goers, both domestic and foreign.

Nevertheless, the challenges of tourism events development related to sustainability are related to the environmental aspects. Tourism events, which directly interact with the TNBTS landscape, especially sports events, need to get more attention. The events that potentially invite massive event goers are vulnerable to affect the environment. There are two challenges faced by the stakeholders. First, the number of jeeps carrying the runners to TNBTS means the exhausted emissions from these vehicles increase, especially when the event was held. Second, related to the potential garbage generated by the participants, before the race, during the race, and post the race.

The third challenge comes from competition with competitors. The Management of TNBTS is faced with two difficult options, either to choose to have collaboration or compete with competitors. In this case, TNBTS has similar product feature and landscape with Mount ljen. From the aspect of location, Mount Ijen is located about $250 \mathrm{~km}$ on the east part of TNBTS area or can be reached through 4-hours drive. Mount ljen also has a tourism event portfolio that is similar to TNBTS. The types of the tourism events that will be held include sports events (Ijen Trail Running, Road to ljen, Mount Ijen Special Gravity), Arts and Entertainment (Jazz ljen), and Recreation (Layang-Layang Wurung Crater). Regarding the managerial aspect, the two tourist destinations are under the authority of the Ministry of Environment and Forestry. Therefore, the stakeholders need to consider what strategies to differentiate from these competitors. 


\section{CONCLUSION}

This study shows that the tourism events in TNBTS mostly come from community initiatives. Tourism events in TNBTS have numerous impacts on economic, social, and environmental aspects. The challenges faced in the development of tourism events in TNBTS include in terms of institutional, sustainability, and competition with competitors. The Government, in this case, the Central Government, needs to immediately realize the concept of Single Destination Single Management. This will clarify the direction of developing tourism events in TNBTS.

The stakeholders also need to consider the sustainability aspects of tourism events in TNBTS. In managing TNBTS, the organizer needs to apply visitor management, especially during the tourism event taking place. This is necessary considering the importance of TNBTS as a conservation area as well as a tourist destination that needs to be managed wisely.

\section{ACKNOWLEDGEMENT}

My greatest gratitude goes to Mrs. Nova (the Central Office of TNBTS), Mr. Sai'in (the Department of Culture and Tourism of East Java), Mr. Sandya and Mr. Anton who have been willing to help and provide the data and the information for this research.

\section{REFERENCES}

[1] Bladen, C., J. Kennell, E. Abson and N. Wilde. 2012. Events management. Routledge. New York.

[2] Bowdin, G., J. Allen, W. O'Toole, R. Harris and I. McDonnell. 2006. Events management. Elsevier Ltd.

[3] Dwyer, L. and E. Wickens. 2011. Event tourism and cultural tourism: Issues and debates: an introduction. Journal of Hospitality Marketing and Management 20(3-4), 239-245.

[4] Getz, D. 1998. Event tourism and the authenticity dilemma. In: Theobald, W. (Ed). Global tourism, $2^{\text {nd }}$ Ed. ButterworthHeinemann. Oxford. 409-427.

[5] Mahadewi, N. M. E. 2012. Atraksi, produk wisata, dan event wisata dari teori ke praktik. Jurnal Perhotelan dan Pariwisata 2(1), 1-10.

[6] Getz, D. 2007. Event studies: theory, research and policy for planned events, $1^{\text {st }}$ Ed. Routledge. Oxford.

[7] Shone, A. and B. Parry. 2010. Successful Event Management, $3^{\text {rd }}$ Ed. SouthWestern. Singapore.
[8] Peraturan Menteri Kehutanan Nomor P.19/menhut-ii/2004. Tentang Kolaborasi Pengelolaan Kawasan Suaka Alam dan Kawasan Pelestarian Alam

[9] Hakim, L. and M. Soemarno. 2017. Biodiversity conservation, community development and geotourism development in Bromo - Tengger - Semeru - Arjuno biosphere reserve. Geojournal of Tourism and Geosites 20(2), 220-230.

[10] Akbar, A. T. and E. Pangestuti. 2017. Peran kuliner dalam meningkatkan citra destinasi pariwisata Taman Nasional Bromo Tengger Semeru. Jurnal Administrasi Bisnis 50(1), 153-159.

[11] Cochrane, J. 2006. Indonesian national parks: understanding leisure users. Annals of Tourism Research 33(4), 979-997.

[12] Sagala, L. P., E. K. S. H. Muntasib, and W. N. Bambang. 2008. Permintaan ekowisata wisatawan mancanegara di Taman Nasional Bromo Tengger Semeru (TNBTS) Jawa Timur. Media Konservasi 13(2), 79-84.

[13] Tasci, A. D. A. and W. C. Gartner. 2007. Destination image and its functional relationships. Journal of Travel Research 45(4), 413-425.

[14] Getz, D. 2013. Planning and staging ecotourism events. In: R. Ballantyne and J. Packer (Eds.), International Handbook on Ecotourism. Edward Elgar Publishing Limited.

[15] Xie, P. F. and K. Gu. 2015. The changing urban morphology: waterfront redevelopment and event tourism in New Zealand. Tourism Management Perspectives 15, 105114.

[16] Nempung, R. I. A., M. Bahruddin, and A. Y. A. Fianto. 2014. Perancangan buku esai fotografi potrait upacara Yadnya Kasada Gunung Bromo Suku Tengger sebagai upaya melestarikan budaya lokal. Jurnal ArtNouveau 2(1), 162-170.

[17] Sutarto, A. 2006. Sekilas tentang masyarakat Tengger. Available at: http://repositori.perpustakaan.kemdikbud. go.id/1106/1/Masyarakat_Tengger.pdf.

[18] Susanti, R. 2015. Event tour De Singkarak Sumatera Barat, pemasaran dan pariwisata yang berkelanjutan. Menara Ekonomi I(2), 38-46.

[19] Dickson, C. and C. Arcodia. 2010. Environmentally sustainable events: a critical review of the literature, dalam Global Events Congress IV: Festivals and 
Events Research: State of the Art, Leeds Metropolitan University. 14, 16.

[20] Richards, G. and R. Palmer, 2012. Eventful cities. Routledge.

[21] Hakim, L. 2006. Kasodo, tourism, and local people perspectives for Tengger Highland conservation. In: Survival of the Commons: Mounting Challenges and New Realities. Proceeding $11^{\text {th }}$ Biennial Conference of International Association for the Study of Common Property IASCP, 1-5.

[22] Lundberg, E., J. Armbrecht, T. D. Andersson, and D. Getz. 2017. The value of events. Routledge. New York.

[23] Gursoy, D., K. Kim and M. Uysal. 2004. Perceived impacts of festivals and special events by organizers: an extension and validation. Tourism Management 25(2), 171-181. 